\title{
THE CONSTRUCT EQUIVALENCE OF THE PIB/SPEEX MOTIVATION INDEX FOR JOB APPLICANTS FROM DIVERSE CULTURAL BACKGROUNDS
}

\author{
P SCHAAP \\ J S BASSON \\ Department of Human Resources Management \\ University of Pretoria
}

\begin{abstract}
The aim of the study was to determine the construct equivalence of the PIB/SpEEx Motivation Index for entry-level job applicants from diverse cultural backgrounds in the public safety and security sector in South Africa. The use of psychometric instruments in South Africa has been criticized because it is said that they are largely based on the values and knowledge of White minority groups and are construct bias and are less valid for other cultural groups. In this study a Black, Asian and White group were included to determine the intercultural equivalence of the internal locus of control and external locus of control constructs underlying the PIB/SpEEx Motivation Index. The results indicate that the constructs of the PIB/SpEEx Motivation Index are not biased and are therefore equivalent for the groups included in the study.
\end{abstract}

\section{OPSOMMING}

Die doel van die studie was om die konstrukgelykwaardigheid van die PIB/SpEEx Motiveringsindeks vir kultureel diverse groepe toetree-applikante in die openbare veiligheidsektor te bepaal. Die algemeenste kritiek teen die gebruik van psigometriese meetinstrumente in Suid-Afrika is dat dit gebaseer is op Blanke waardes en kennis en dat dit gevolglik konstruksydig en minder geldig is vir ander kultuurgroepe. In hierdie studie is Swart, Asiër en Blanke groepe gebruik in die bepaling van die interkulturele gelykwaardigheid van die interne en die eksterne lokus van beheer konstrukte onderliggend aan die PIB/SpEEx Motiveringsindeks. Die resultate toon dat die PIB/SpEEx Motiveringsindeks nie sydig meet nie en dat die konstrukte dus gelykwaardig is vir die verskillende kultuurgroepe.

Motivational orientations as demonstrated in the work context may differ because people have unique personality characteristics and because of the effect of changing situational factors (Steers \& Porter, 1991). Individual employees may have a motivational orientation according to which they perceive themselves as responsible for decisions that can affect the outcomes of their behaviour, or an orientation according to which the outcomes of their behaviour can be attributed to factors beyond their control (Bergh, 1999). It must be recognised that people's disposition toward a specific motivational orientation could vary in and between different situations.

Rotter (1966) coined the term locus of control to explain people's expectation that the outcomes of their behaviour are either internally or externally controlled. The concept has its foundations in the social learning theory and the attribution theory (Schepers, 1995)). The social learning theory stresses that reinforcement, regard and gratification play a crucial role in determining behaviour. An individual's potential for eliciting specific behaviour depends on his or her expectations regarding the outcome of such behaviour in terms of specific reinforcement and the incentive value of the reinforcement. Individuals therefore perceive expectations and incentives that are linked to specific behaviour as an important motivation to behave in a certain way. The attribution theory is linked to the social learning theory in that attribution involves trying to understand, by localising the cause, why events and one's behaviour have certain outcomes. Causes are attributed to either internal factors within the individual's control or to external factors in the situation. Rotter (1966) refers to the attribution of cause as the locus of causality. When the cause is attributed to internal factors that are within the individual's control, this is known as an internal locus of control. On the other hand, when the cause is attributed to external factors beyond the individual's control (for example: luck, fate, other people and circumstances) it is known as an external locus of control.
Since the development of the first locus of control scale by Rotter (1966), better known as the Internal-External Locus of Control scale, the concept has been extensively researched. Van Daalen, Van Niekerk and Pottas (1989) point out that Rotter's (1966) original article was cited 1340 times between 1969 and 1977. Hersch and Scheibe (1967) were the first to come up with the notion that locus of control should be viewed as a multidimensional construct. Various authors have since supported this concept (Schepers, 1995; Anderson, Madonna, Baily \& Wesley, 1987; Duffy, Shiflett \& Downey, 1977). Based on the results of factor analysis, Schepers (1995), Blau (1993), Schaap (1998), and Macan and Trusty (1996) concluded that internal and external loci of control are separate constructs and not opposites in a continuum. Macan and Trusty (1996) have found that the two constructs relate differentially to other constructs, in further support of the contention that locus of control is a multidimensional concept.

According to Van Daalen et al. (1989), the situation-specific trend toward the measurement of personality that is based on Mischel's (1968) and Kurt Lewin's (1935) views should be welcomed. Situation-specific scales tend to emphasise that personality functioning is a reflection of the interaction of personality and the psychological situation. Specific locus of control scales have been developed to be relevant to, for instance, health situations, educational settings, political behaviour, religious beliefs and behaviour, economic behaviour and work behaviour (Van Daalen, et al.). Erasmus (2001) stresses that personality assessments in a work context should always be done only in terms of job-related requirements. Bergh (1999) points out that when specific personality-related variables and work-related behaviours are isolated and compared, much stronger relationships are found. Erasmus (2001) strongly supports the notion that to ensure job relevant assessments there should be a "fit" between personality measures and work-related behaviour.

The role of locus of control in organisational behaviour and work performance has been well researched (Robbins, 2001; Blau, 1993; Spector, 1982). Studies have shown that there are 
significant relationships between locus of control perceptions and work performance, occupational attainment, job satisfaction, career satisfaction, organisational commitment, intrinsic and achievement motivation, leadership, managerial behaviour, entrepreneurial behaviour and career maturity (Spector, 1982; Blau, 1993; Macan \& Trusty, 1996; Van Staden, Schepers \& Rieger, 2000; Le Roux, Schmidt \& Schepers, 1997; Erwee, 1986). There is thus sufficient evidence that locus of control plays an important role in organisational behaviour and work performance.

Concerning individual performance, Spector (1982) predicted that when tasks or organisational demands require initiative and independent action, an employee with an internal locus of control would be more suitable, and when compliance is sought, an employee with an external locus of control would be more appropriate. In support of Spector's prediction, Blau (1993) reported statistically significant, positive correlations between an internal locus of control and initiative performance as well as statistically significant, positive correlations between external locus of control and compliant performance. The results imply that "internals" look to themselves for direction and demonstrate initiative and independence of action in the work context, while "externals" depend on outside factors such as their supervisors or company rules.

Potential Index Associates developed the Potential Index Batteries/Situation Specific Evaluation Expert's (PIB/SpEEx) Motivation Index (Revised edition) for occupation related assessments (Erasmus, 2001). The PIB/SpEEx Motivation Index consists of an internal and external locus of control component. It can be defined as a basic or core competency related to situation-specific work performance. A job profiling system known as the Job Profiling Expert (JP EXPERT) helps to determine the link between and the importance of the internal or external locus of control scale for a specific job in a specific context (Erasmus, 2001).

Research indicates that the PIB/SpEEx Motivation Index is a valid predictor of work and training performance within specific situations (Kriel, 1999; Kruger, 1999; Grobler 2000). Kriel (1999) found a statistically significant, positive correlation between internal locus of control and academic performance in journalism and drama courses. Kruger (1999) reported statistically significant, positive correlations between an internal locus of control and initiative as work performance criteria and between an internal locus of control and quality of work as performance criteria. Grobler (2000) reported a statistically significant, positive correlation between an external locus of control and academic performance in traffic law by trainee policemen. Academic performance in traffic law by trainee policemen can be conceptualised as a compliance type of performance criterion. Kruger's (1999) and Groblers's (2000) studies appear to support the notion of the relationship between an external locus of control and an compliance type of performance and an internal locus of control and an initiative type of performance. Thus, there is external criteria related evidence of the construct validity of the PIB/SpEEx Motivation Index as a measure of locus of control in the occupational context.

The significance of psychological testing to optimal utilisation of human resources in industry is no longer a controversial issue. This is also true for newly developed nations in many parts of the world. The rapid increase in industrialisation and expanding educational facilities call for effective selection, placement and development aids in all fields of employment (Anastasi \& Urbina, 1997).

The testing of persons with highly dissimilar cultural backgrounds has received increasing attention since the 1950s (Anastasi \& Urbina, 1997). In South Africa, recent legislation emphasises the issue of cross-cultural psychological testing in a work context. The Employment Equity Act of South Africa (Republic of South Africa, 1998) places all test developers and users under an obligation to consider the impact of psychometric assessments on different groups as carefully as they consider other technical psychometric issues. The importance of the incorporation of this requirement into the design of psychometric instruments cannot be overemphasised. The possibility that some tests may be biased against certain groups has become a matter of primary concern in South Africa (Schaap, 2001).

Cross-cultural studies suggest that linguistic proficiencies, attitudes, motivation, values and culture-specific factors play an important role in test response pattern differences between groups (Owen, 1996). Cross-cultural studies have shown that locus of control beliefs involve different patterns of salience across diverse groups (Buriel, 1981; Chiu, 1988; Dean, 1984; Heaven, Rajab \& Bester, 1986; Kishor, 1983; Kureshi \& Husain, 1981; Mirowsky \& Ross, 1984; Young \& Shorr, 1986). The relationship between culture and locus of control has been well researched, but, according to Otterman (1999), it is important to be cautious and critical in our evaluation of research which links locus of control and culture. Otterman specifically cautions against inferring that culture determines the degree of internal or external control without considering the effect of other relevant factors.

Linguistic proficiency is generally regarded as the most important single moderator of performance on assessment measures in South Africa (Grieve, 2001). Psychometric tests in South Africa that are in verbal format are generally only available in Afrikaans or English. Studies have shown that the average English language proficiency of grade 12's in South Africa who indicate an African language as their first language are below the acceptable functional literacy level, based on the results of English Literacy Skills Assessments (ELSA) (Horne, 2001). Horne indicates that 40-60\% of matriculants who speak an African language as their first language have not reached a Grade 12 English functional literacy level by the time they leave school. Thus, a lack of English language proficiency could have a detrimental effect on an individual's response patterns on English test forms. It has been suggested that cognitive and linguistic abilities are strongly related and determine the level of understanding of verbal material (Ungerer, 1999). Insofar as the effect of specific language proficiency levels and related cognitive abilities are controlled for, the effect of other cultural-specific factors on test response patterns can become more prominent.

Construct equivalence is the most fundamental question when test responses are compared across different cultures, because it concerns the nature and essence of what is being measured (Owen, 1996). According to Reynolds (1982), constructs are equivalent when a test is shown to measure the same hypothetical traits (psychological constructs) in one group as in another, or when it measures the same trait, with similar degrees of accuracy. Bechger, Van den Wittenboer, Hox and De Glopper (1999) distinguish between two aspects of construct equivalence; firstly, the similarity of the theoretical mechanisms that underlie behaviour in each group and, secondly, the similarity of the pattern of relations of a test to other measures in each group. Van de Vijver and Leung (1997) defined the first aspect, which is the focus of this article, as the similarity in correlations (pattern of relations) of items of an instrument with respect to each group. Constructs are equivalent for different cultural groups when the test reliabilities, item discrimination values and factor structures are similar for these groups. Constructs that are equivalent for different cultural groups indicate the absence of construct bias in an instrument.

The purpose of this study was to determine the construct equivalence of the PIB/SpEEx Motivation Index for entry-level job applicants from diverse cultural backgrounds in the public safety and security sector in South Africa. 


\section{METHOD}

The method followed in this study is discussed in terms of the sample, the measuring instrument and analytical procedure used.

\section{Sample}

A convenience sample of 1663 respondents was drawn for the analysis of the English version of the PIB/SpEEx's Motivation (the locus of control) Index. The sample was drawn from a population of 13192 entry-level job applicants in the public safety and security services sector. These applicants completed the English Reading Comprehension, English Spelling, English Vocabulary and Mental Alertness tests of the PIB/SpEEx battery. The Mental Alertness test is an English version of a measure of verbal reasoning ability and an index of general intellectual ability. The respondents were subsequently selected on the basis of their rank-order, from high to low, on the total score of all five tests. A total of $12,6 \%$ of the highest-scoring respondents was included in the final sample. The sample can thus be considered relatively homogeneous in terms of English literacy skills and verbal reasoning abilities. All the data were acquired with the informed consent of the respondents and under the supervision of registered psychologists, and were dealt with in a confidential manner.

The biographical information of the sample is set out in Table 1 .

TABLE 1

BIOGRAPHICAL INFORMATION OF THE RESPONDENTS

\begin{tabular}{lrrcc}
\hline & Frequency & Percent & Valid \% & Cumulative \% \\
\hline GENDER: & & & & \\
Male & 1405 & 84,5 & 84,6 & 84,6 \\
Female & 255 & 15,3 & 15,4 & 100,0 \\
Total & 1660 & 99,8 & 100,0 & \\
Unknown & 3 & 0,2 & & \\
Total & 1663 & 100,0 & & \\
\hline
\end{tabular}

CULTURAL GROUP:

\begin{tabular}{lrrrr} 
Black & 880 & 52,9 & 52,9 & 52,9 \\
White & 117 & 7,0 & 7,0 & 60,0 \\
Asian & 666 & 40,0 & 40,0 & 100,00 \\
Total & 1663 & 97,6 & 100,0 & \\
\hline
\end{tabular}

\section{LANGUAGE:}

\begin{tabular}{lrrrr} 
English & 716 & 43,1 & 48,2 & 49,2 \\
Afrikaans & 37 & 2,2 & 2,5 & 50,7 \\
Zulu & 223 & 13,4 & 15,0 & 65,7 \\
Sepedi & 123 & 7,4 & 8,3 & 74,0 \\
Seswati & 6 & 0,4 & 0,4 & 74,4 \\
Tsonga & 63 & 3,8 & 4,2 & 78,6 \\
Tswana & 89 & 5,4 & 6,0 & 84,6 \\
Ndebele & 12 & 0,7 & 0,8 & 85,4 \\
Venda & 86 & 5,2 & 5,8 & 91,2 \\
Sesotho & 96 & 5,8 & 6,5 & 97,6 \\
Xhosa & 35 & 2,1 & 2,4 & 100,0 \\
Total & 1486 & 89,4 & 100,0 & \\
Unknown & 177 & 10,6 & & \\
Total & 1663 & 100,0 & & \\
\hline
\end{tabular}

\section{QUALIFICATIONS:}

\begin{tabular}{lrrrr} 
Matric & 1358 & 81,7 & 82,6 & 82,6 \\
Diploma & 213 & 12,8 & 12,9 & 95,5 \\
Degree & 72 & 4,3 & 4,4 & 100,0 \\
Total & 1645 & 98,9 & 100,0 & \\
Unknown & 18 & 1,1 & & \\
Total & 1663 & 100,0 & & \\
\hline
\end{tabular}

The sample consisted of 880 Black; 666 Asian and 117 White respondents. Of the respondents, $41 \%$ indicated an African language as their first language. The African language groups that were predominantly represented were Zulu, Tswana, Venda and Sesotho. In addition, 2,5\% of the respondents indicated that they speak Afrikaans and $48,2 \%$ of the respondents indicated that they speak English. A total of $10,6 \%$ of the respondents did not indicate their home language.

Most of the respondents $(82,6 \%)$ had a matriculation certificate. A total of $12,9 \%$ of respondents had obtained a diploma or degree. Only $1,1 \%$ of the respondents did not indicate their qualification(s). The sample consisted of $84,6 \%$ males and $15,4 \%$ females.

\section{Measuring instrument}

The PIB/SpEEx Motivation Index has been standardised for the various cultural groups in South Africa. The generic norm group currently consists of 9305 respondents, of which approximately $65 \%$ are Black, $18 \%$ are Asian, $12 \%$ are White, and $8 \%$ are Coloured. The latest version of the PIB/SpEEx Motivation Index consists of two locus of control subscales with 20 items each and rated on a seven-point scale. The seven-point scale is anchored at the extreme values 1 and 7 as low and high respectively (Erasmus, 2001). Factor analyses have indicated a clear and welldefined simple structure for the PIB/SpEEx Motivation Index consisting of an Internal Locus of Control and External Locus of Control subscale (Schaap, 1998). The reliability coefficients reported for the Internal Locus of Control and External Locus of Control scales are 0,80 and higher and can be considered acceptable (Schaap, 1998).

\section{Analytical procedure}

The construct equivalence of the PIB/SpEEx Motivation Index for Black, Asian and White South Africans was evaluated by computing coefficients for internal consistency (alpha) and by conducting item and factor analyses respectively. The SPSS (SPSS Inc., 1996) and EQS (Bentler, 1995) programme were used to perform the required analyses.

An item analysis was performed in respect of each group to determine the characteristics of items included in the constructs of the PIB/SpEEx motivation index. Item-total correlations provide an indication of the discrimination value of an item. A discrimination value of below 0,20 is generally not considered acceptable (Anastasi \& Urbina, 1997, DeVellis, 1991). Item discrimination values and item reliability coefficients can provide valuable information on the functioning of individual items in respect of each of the cultural groups. It would be reasonable to expect that items should at least meet the minimum requirements in terms of their contribution to the construct being measured in cross-cultural contexts.

Comparing the reliabilities of an instrument in respect of different cultural groups can be considered a preliminary test for construct equivalence. The observation of dissimilar reliability coefficients can provide valuable clues about measurement accuracy and the appropriateness of an instrument for cross-cultural comparison (Van de Vijver \& Leung, 1997). The statistical significance of differences between Cronbach coefficients alphas was determined by using Feldt's test statistic (Charter \& Feldt, 1996). The significance value of Feldt's test statistic is sample-sensitive and increases with sample size. Although a small difference in the reliability coefficient for large independent samples might prove to be statistically significant, the difference could be so small that it has little practical significance.

The equivalence of psychological structures has been studied mostly by means of factor analysis (Van de Vijver \& Leung, 1997). For the purposes of this study, both exploratory and confirmatory factor analytical methods were applied. This 
approach allows the researcher(s) to take advantage of the relative strengths of each method in relation to that of others. Exploratory factor extraction procedures provide the most parsimonious explanation of the common variance underlying a correlation matrix. By contrast, confirmatory factor extraction procedures determine whether the data are consistent with a hypothesized factor structure. Confirmation of a hypothesized factor structure may be obtained by using confirmatory factor analysis procedure, despite the fact that an exploratory factor analysis would yield a striking different factor structure for specific data (Tinsley \& Tinsley, 1987). This may call for a more rigorous process using both methods in the analysis of data, instead of applying a single method. Van de Vijver and Poortinga (2000) confirm that it may be possible to apply both exploratory and confirmatory approaches on cross-cultural data. According to Van de Vijver and Poortinga (2000), the latter may then provide a statistically more adequate test of the structural equivalence of multiple-group data. Compared to exploratory factor analytical procedures, confirmatory factor analysis is a more versatile tool to test for hierarchically linked hypotheses of cross-cultural invariance.

DeVellis (1991) claims unequivocally that exploratory factor analysis can be successfully applied to confirm hypotheses with regard to theoretical constructs. The distinction between testing and creating hypotheses in factor analysis is not clear (Child 1990). The criteria used in exploratory factor analysis to confirm significant factors and the equivalence of factors between groups is the following (DeVellis, 1991):

- the extent to which anticipated factor groupings are confirmed in the factor analysis for the groups being compared;

- the number of significant factors are similar for both groups;

- factor solutions that are clear or well-defined and can be interpreted similarly for both groups; and

- factor loadings are similar for the groups being compared.

In this study, the Principal Axis Factoring (PAF) extraction method and oblique rotation (Direct Oblimin) were used to generate the hypothetical factor solutions for the PIB/SpEEx Motivation Index. Kaiser's criterion (1961), the parallel method of Horn (1965) and the scree-plots (Cattell 1966) were used to verify the number of significant factors with regard to each of the cultural groups (Child, 1990). Horn's (1965) method entails contrasting the eigenvalues of a correlation matrix of random uncorrelated variables with those of the dataset in question, based on the same sample size and the same number of variables. Factors of the matrix of interest which have eigenvalues greater than those of the random comparison matrix would be retained. According to Zwick and Velicer (1986), Horn's (1965) method provides the most accurate estimate of the number of true factors in a complex dataset. Tucker's (1951) congruence coefficient was used to calculate the level of congruence of the rotated factor solutions for the two groups using the targeted rotation procedure advocated by McDonald (1985), to indicate the level of factor agreement across cultural groups.

Preliminary single group confirmatory factor analysis was conducted to test the extent to which the data fitted the measurement model in respect to each of the cultural groups. MacCallum (1986) and Byrne, Shavelson and Muthén (1989) pointed out the necessity for determining the model fit for each of the groups separately before multiple-group comparisons are made. If a model fits very badly in a onegroup analysis, it is likely that the model will not fit as part of a larger multisample analysis (Bentler, 1995). Maximum likelihood estimation was used via the EQS structural equation software. The BentlerBonnett Non-normed Fit Index (NNFI), the Comparative Fit Index (CFI), the Bollen Nonnormed Fit Index (IFI), the Root Mean Squared Error of Approximation (RMSEA) and the Model Chi-square were used as model fit indices. The chance of obtaining a non-significant chi-square becomes extremely small with large sample sizes. The ratio of chisquare to degrees of freedom has been proposed as a better measure although it appears to suffer from arbitrary standards of interpretation (Kelloway, 1998; Medskar, Williams \& Holahan, 1994). The CFI, NNFI and the IFI are considered to be relatively robust for the effect of sample size (Bentler, 1990).

Multiple-group confirmatory factor analysis is useful in an evaluation of the equivalence of covariance matrixes, number of factors, factor variances, factor covariances and factor loadings for multiple groups (Van de Vijver \& Harsveld, 1994). The equality of the covariance matrix is normally tested first, followed by subsequent analyses of nested models (Van de Vijver \& Harsveld, 1994). A set of hierarchically nested models that successively increases the number of equality constraints was used to test the equivalence of constructs with respect to the Black, Asian and White groups. The constraints were imposed in the sequence proposed by Vandenberg and Self (1993), starting with equality in the number of factors, followed by the equality of factor variances and factor covariances and ending with equality of factor loadings. The incremental change in the chi-square with each constraint imposed provides an indication of the extent to which the constraints could be considered reasonable for the groups. The chi-square, CFI, NNFI, IFI and RMSEA statistics were used as overall goodness of fit indices for the nested models. The Lagrange Mutiplier (LM) Test was used to evaluate whether each of the cross-group equality constraints was reasonable (Bentler, 1995). The LM Test provided the means to identify specific constraints (between any two groups) that may have had a substantial effect on the lack of overall model fit for multiple groups. The release of one or more constraints with high probability values could lead to a substantial improvement of the overall model fit for multiplegroup comparisons.

Item aggregate values (item parcels) were calculated to control for artifacts in item groupings or factors that have no psychological importance, due to the effect of differential item skewness (Comrey \& Lee, 1992; Gorsuch 1997). Bagozzi and Heatherton (1994) indicate that the indices obtained from a confirmatory factor analysis could be an underestimate of the model fit values. This could happen when factors contain a large number of items. Bagozzi and Heatherton (1994) propose the calculation of item aggregates to obtain more accurate estimates of model fit indices. Item aggregates were built according to rational and theoretical criteria. It was assumed that each item was an alternative but equivalent indicator of the construct to which it had been allocated. PIB/SpEEx Motivation Index was divided into 14 aggregates of which 12 consisted of three items each and two consisted of two items each. Table 2 sets out how the items were allocated to form aggregates.

TABLE 2

ITEM AGgREgATES OF THE PIB/SPEEX MOTIVATION INDEX

\begin{tabular}{lccccccc}
\hline $\begin{array}{l}\text { Internal locus of control } \\
(20 \text { items })\end{array}$ & \multicolumn{7}{c}{$\begin{array}{l}\text { External locus of control } \\
(20 \text { items })\end{array}$} \\
\hline Int1 & 2 & 3 & 4 & Ext1 & 1 & 5 & 8 \\
Int2 & 6 & 7 & 9 & Ext2 & 10 & 11 & 15 \\
Int3 & 12 & 13 & 14 & Ext3 & 18 & 20 & 21 \\
Int4 & 16 & 17 & 19 & Ext4 & 24 & 25 & 28 \\
Int5 & 22 & 23 & 26 & Ext5 & 32 & 33 & 34 \\
Int6 & 27 & 29 & 30 & Ext6 & 35 & 36 & 37 \\
Int7 & 31 & 38 & & Ext7 & 39 & 40 & \\
\hline
\end{tabular}




\section{RESULTS}

The results of the item analysis of the External Locus of Control scale for the different groups are given in Table 3. Only Item 11 had an item-total correlation (discrimination value) lower than 0,20 for the Asian group. The remaining items all had acceptable discrimination values. A discrimination value of below 0,20 is generally considered not acceptable (Anastasi \& Urbina, 1997; DeVellis, 1991). The items with the low item-total correlations also had relatively low item reliabilities. With reference to the Black group, all the items appeared to have acceptable discrimination values and item reliabilities. The External Locus of Control scale's alpha coefficients of the Black, Asian and White groups were 0,$77 ; 0,79$; and 0,83 respectively. Feldt's statistic indicates that the difference between the reliability coefficients of the Black and White groups is statistically significant at the $5 \%$ probability level. The difference in the reliability coefficients in respect of the White and Asian groups and the Asian and Black groups were all statistically non-significant. The results of the item and reliability analyses in terms of the External Locus of Control scale revealed only small differences in the construct with regard to the Black and Asian groups and the Asian and White groups. The statistical difference in the reliability coefficients of the Black and White groups indicated that differences in the response pattern did exist with regard to these groups.

The item-analysis results for the Internal Locus of Control scale are set out in Table 4 . All the item-total correlations are above 0,20 in respect of the Asian group. One item, namely item 30, has an item-total correlation lower than 0,20 for the Black group. The Internal Locus of Control scale's alpha coefficients of the Black, Asian and White groups were 0,82; 0,82 ; and 0,89 respectively. The reliability coefficient of the
White group differed significantly $(p \leq 0,05)$ from the reliability coefficients of the Black and Asian groups. The results of the item and reliability analyses in terms of the Internal Locus of Control scale revealed little difference in the construct with respect to the Black and Asian groups. There were some evidence of differences on the internal locus of control construct when the Black and Asian groups were compared to the White group.

The results of the principal axis factor analysis performed on the PIB/SpEEx Motivation Index indicated small differences in the factor structures for the Black, Asian and White groups. The sample adequacy for the Black, Asian and White groups were both adequate, according to the KaiserMeyer-Olkin (MSA) measure of sample adequacy (Kim \& Mueller, 1978) and Bartlett's significance test (Gorsuch, 1983). The MSA-values were 0,$83 ; 0,82$; and 0,84 for the Black, Asian and White groups respectively, and can be considered highly acceptable.

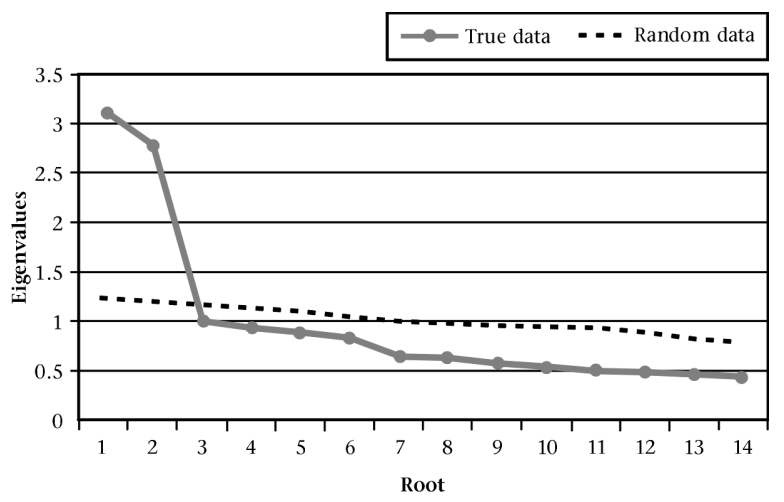

Figure 1: Scree-plot (Black group)

TABLE 3

ITEM ANALYSIS OF THE EXTERNAL LOCUS OF CONTROL SUBSCALE IN RESPECT OF THE DIFFERENT CULTURAL GROUPS

\begin{tabular}{|c|c|c|c|c|c|c|c|c|c|}
\hline & \multicolumn{3}{|c|}{ Black group $(n=880)$} & \multicolumn{3}{|c|}{ Asian group $(n=666)$} & \multicolumn{3}{|c|}{ White group $(n=117)$} \\
\hline & $\begin{array}{l}\text { Corrected } \\
\text { Item- } \\
\text { Total } \\
\text { Correlation }\end{array}$ & $\begin{array}{c}\text { Item } \\
\text { Reliability }\end{array}$ & $\begin{array}{l}\text { Alpha } \\
\text { if Item } \\
\text { Deleted }\end{array}$ & $\begin{array}{c}\text { Corrected } \\
\text { Item- } \\
\text { Total } \\
\text { Correlation }\end{array}$ & $\begin{array}{c}\text { Item } \\
\text { Reliability }\end{array}$ & $\begin{array}{l}\text { Alpha } \\
\text { if Item } \\
\text { Deleted }\end{array}$ & $\begin{array}{l}\text { Corrected } \\
\text { Item- } \\
\text { Total } \\
\text { Correlation }\end{array}$ & $\begin{array}{c}\text { Item } \\
\text { Reliability }\end{array}$ & $\begin{array}{l}\text { Alpha } \\
\text { if Item } \\
\text { Deleted }\end{array}$ \\
\hline Item 1 & 0,248 & 0,462 & 0,764 & 0,342 & 0,470 & 0,770 & 0,377 & 0,528 & 0,823 \\
\hline Item 5 & 0,240 & 0,411 & 0,764 & 0,372 & 0,569 & 0,768 & 0,257 & 0,556 & 0,830 \\
\hline Item 8 & 0,286 & 0,470 & 0,761 & 0,304 & 0,521 & 0,773 & 0,365 & 0,463 & 0,824 \\
\hline Item 10 & 0,350 & 0,627 & 0,756 & 0,354 & 0,573 & 0,769 & 0,291 & 0,312 & 0,827 \\
\hline Item 11 & 0,272 & 0,503 & 0,762 & $0,157^{*}$ & 0,257 & 0,783 & 0,370 & 0,502 & 0,823 \\
\hline Item 15 & 0,364 & 0,603 & 0,755 & 0,373 & 0,513 & 0,768 & 0,571 & 0,711 & 0,814 \\
\hline Item 18 & 0,230 & 0,427 & 0,765 & 0,233 & 0,461 & 0,780 & 0,319 & 0,376 & 0,826 \\
\hline Item 20 & 0,466 & 0,598 & 0,751 & 0,417 & 0,391 & 0,769 & 0,504 & 0,768 & 0,817 \\
\hline Item 21 & 0,421 & 0,760 & 0,751 & 0,401 & 0,561 & 0,766 & 0,430 & 0,497 & 0,821 \\
\hline Item 24 & 0,368 & 0,520 & 0,756 & 0,356 & 0,464 & 0,769 & 0,419 & 0,472 & 0,822 \\
\hline Item 25 & 0,322 & 0,599 & 0,758 & 0,255 & 0,381 & 0,775 & 0,464 & 0,708 & 0,819 \\
\hline Item 28 & 0,303 & 0,541 & 0,760 & 0,317 & 0,572 & 0,772 & 0,380 & 0,623 & 0,823 \\
\hline Item 32 & 0,421 & 0,720 & 0,751 & 0,418 & 0,642 & 0,765 & 0,399 & 0,542 & 0,822 \\
\hline Item 33 & 0,250 & 0,371 & 0,763 & 0,364 & 0,387 & 0,770 & 0,414 & 0,636 & 0,821 \\
\hline Item 34 & 0,420 & 0,796 & 0,751 & 0,356 & 0,570 & 0,769 & 0,382 & 0,627 & 0,823 \\
\hline Item 35 & 0,359 & 0,674 & 0,756 & 0,398 & 0,664 & 0,766 & 0,442 & 0,649 & 0,820 \\
\hline Item 36 & 0,303 & 0,599 & 0,760 & 0,318 & 0,533 & 0,772 & 0,427 & 0,708 & 0,821 \\
\hline Item 37 & 0,419 & 0,667 & 0,752 & 0,459 & 0,740 & 0,762 & 0,479 & 0,550 & 0,818 \\
\hline Item 39 & 0,255 & 0,502 & 0,764 & 0,408 & 0,739 & 0,765 & 0,375 & 0,717 & 0,824 \\
\hline Item 40 & 0,367 & 0,500 & 0,756 & 0,408 & 0,406 & 0,768 & 0,439 & 0,379 & 0,821 \\
\hline
\end{tabular}


TABLE 4

ITEM ANALYSIS OF THE INTERNAL LOCUS OF CONTROL SUBSCALE IN RESPECT OF THE DIFFERENT CULTURAL GROUPS

\begin{tabular}{|c|c|c|c|c|c|c|c|c|c|}
\hline & \multicolumn{3}{|c|}{ Black group $(n=880)$} & \multicolumn{3}{|c|}{ Asian group $(n=666)$} & \multicolumn{3}{|c|}{ White group $(n=117)$} \\
\hline & $\begin{array}{l}\text { Corrected } \\
\text { Item- } \\
\text { Total } \\
\text { Correlation }\end{array}$ & $\begin{array}{c}\text { Item } \\
\text { Reliability }\end{array}$ & $\begin{array}{l}\text { Alpha } \\
\text { if Item } \\
\text { Deleted }\end{array}$ & $\begin{array}{l}\text { Corrected } \\
\text { Item- } \\
\text { Total } \\
\text { Correlation }\end{array}$ & $\begin{array}{c}\text { Item } \\
\text { Reliability }\end{array}$ & $\begin{array}{l}\text { Alpha } \\
\text { if Item } \\
\text { Deleted }\end{array}$ & $\begin{array}{l}\text { Corrected } \\
\text { Item- } \\
\text { Total } \\
\text { Correlation }\end{array}$ & $\begin{array}{c}\text { Item } \\
\text { Reliability }\end{array}$ & $\begin{array}{l}\text { Alpha } \\
\text { if Item } \\
\text { Deleted }\end{array}$ \\
\hline Item 2 & 0,462 & 0,607 & 0,796 & 0,432 & 0,733 & 0,791 & 0,576 & 0,861 & 0,871 \\
\hline Item 3 & 0,505 & 0,669 & 0,794 & 0,450 & 0,542 & 0,792 & 0,622 & 0,810 & 0,870 \\
\hline Item 4 & 0,373 & 0,735 & 0,800 & 0,344 & 0,605 & 0,796 & 0,601 & 0,896 & 0,870 \\
\hline Item 6 & 0,338 & 0,590 & 0,802 & 0,269 & 0,474 & 0,801 & 0,309 & 0,552 & 0,881 \\
\hline Item 7 & 0,404 & 0,682 & 0,798 & 0,392 & 0,613 & 0,793 & 0,568 & 0,767 & 0,872 \\
\hline Item 9 & 0,450 & 0,632 & 0,796 & 0,502 & 0,658 & 0,788 & 0,580 & 0,862 & 0,871 \\
\hline Item 12 & 0,485 & 0,671 & 0,795 & 0,525 & 0,653 & 0,788 & 0,591 & 0,903 & 0,870 \\
\hline Item 13 & 0,323 & 0,578 & 0,803 & 0,320 & 0,627 & 0,799 & 0,439 & 0,729 & 0,876 \\
\hline Item 14 & 0,450 & 0,576 & 0,797 & 0,524 & 0,582 & 0,789 & 0,522 & 0,637 & 0,873 \\
\hline Item 16 & 0,413 & 0,683 & 0,797 & 0,384 & 0,624 & 0,794 & 0,452 & 0,652 & 0,875 \\
\hline Item 17 & 0,402 & 0,677 & 0,798 & 0,463 & 0,589 & 0,791 & 0,600 & 0,765 & 0,871 \\
\hline Item 19 & 0,410 & 0,752 & 0,797 & 0,230 & 0,385 & 0,803 & 0,396 & 0,60 & 0,877 \\
\hline Item 22 & 0,329 & 0,584 & 0,802 & 0,369 & 0,567 & 0,795 & 0,453 & 0,656 & 0,875 \\
\hline Item 23 & 0,387 & 0,637 & 0,799 & 0,417 & 0,656 & 0,792 & 0,534 & 0,858 & 0,872 \\
\hline Item 26 & 0,418 & 0,792 & 0,797 & 0,297 & 0,529 & 0,799 & 0,420 & 0,730 & 0,876 \\
\hline Item 27 & 0,441 & 0,745 & 0,796 & 0,547 & 0,697 & 0,787 & 0,634 & 0,881 & 0,869 \\
\hline Item 29 & 0,321 & 0,563 & 0,803 & 0,270 & 0,431 & 0,800 & 0,333 & 0,520 & 0,879 \\
\hline Item 30 & $0,121^{*}$ & 0,228 & 0,815 & 0,271 & 0,450 & 0,800 & 0,215 & 0,351 & 0,883 \\
\hline Item 31 & 0,312 & 0,603 & 0,804 & 0,255 & 0,462 & 0,802 & 0,408 & 0,763 & 0,877 \\
\hline \multirow[t]{2}{*}{ Item 38} & 0,319 & 0,589 & 0,803 & 0,392 & 0,646 & 0,793 & 0,632 & 1,036 & 0,869 \\
\hline & \multicolumn{3}{|c|}{ Scale reliability: Black group: 0,818} & \multicolumn{3}{|c|}{ Asian group: 0,818} & \multicolumn{3}{|c|}{ White group: 0,885} \\
\hline
\end{tabular}

Item-total correlation: * $<0,20$

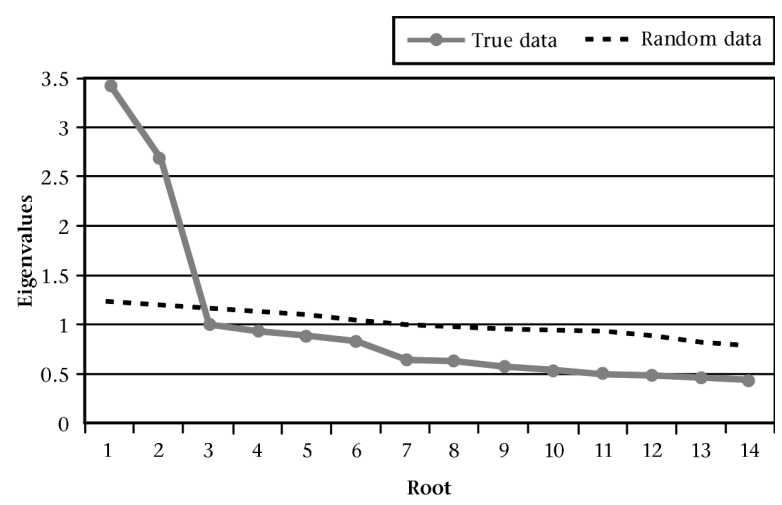

Figure 2: Scree-plot (Asian group)

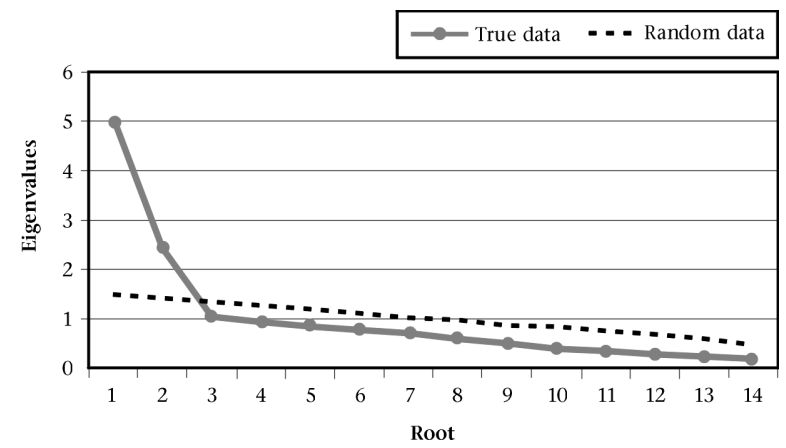

Figure 3: Scree-plot (White group)
The factor analyses resulted in the extraction of a total of 14 factors for the Black, Asian and White groups. With reference to Figure 1 (Black group), Figure 2 (Asian group) and Figure 3 (White group), two significant factors were identified for the Black, Asian and White groups, based on the results of the screetest (Cattell, 1966) and Horn's (1965) criteria. A clear break could be observed in the scree-plot between roots two and three for all the groups. The curve of the eigenvalues of the random dataset (the broken line) intersects the curve of the eigenvalues for the real dataset (the solid line) between roots two and three for each of the groups, indicating two significant factors (Horn, 1956). The results set out in Table 5, indicated that the first two significant factors explained $42,38 \% ; 43,48 \%$ and $52,89 \%$ of the total variance respectively for the Black, Asian and White groups. Compared to the scree-test and Horn's criteria, Kaiser's (1961) criteria gave an overestimate of the number of true factors for the White dataset. Table 6 shows the proposed two-factor model for the Black, Asian, and White groups, which is well defined and interpretable and yields a simple structure. Factor loadings of 0,30 and higher were considered acceptable (Tabachnick \& Fidell, 1989). Small deviations from the 0,30 criteria were allowed, to account for possible differences in sample homogeneity.

Factor 1 can be identified as an internal locus of control construct and Factor 2 can be identified as an external locus of control construct for the Black, Asian and White groups.

The low intercorrelations between the factors in Table 6 indicate that the Internal and External Locus of Control scales were not related strongly for the different groups included in the study. This finding supports Schepers's (1995) finding that internal and external locus of control should be regarded as separate constructs and not as bi-polar opposites of a continuum.

As illustrated in Table 7, the congruence coefficients for the Internal and External Locus of Control scales varied from 0,96 to 
TABLE 5

FACTOR EIGENVALUES AND VARIANCE EXPLAINED OF ITEM AGGREGATES IN RESPECT OF THE DIFFERENT CULTURAL GROUPS

\begin{tabular}{|c|c|c|c|c|c|c|c|c|c|}
\hline \multirow[b]{2}{*}{ Root } & \multicolumn{3}{|c|}{ Black group $(n=880)$} & \multicolumn{3}{|c|}{ Asian group $(n=666)$} & \multicolumn{3}{|c|}{ White group $(n=117)$} \\
\hline & $\begin{array}{l}\text { Eigen- } \\
\text { values } \\
\text { Total }\end{array}$ & $\begin{array}{c}\% \text { of } \\
\text { Variance }\end{array}$ & Cumulative & $\begin{array}{c}\text { Eigen- } \\
\text { values } \\
\text { Total }\end{array}$ & $\begin{array}{c}\% \text { of } \\
\text { Variance }\end{array}$ & Cumulative & $\begin{array}{c}\text { Eigen- } \\
\text { values } \\
\text { Total }\end{array}$ & $\begin{array}{c}\% \text { of } \\
\text { Variance }\end{array}$ & Cumulative \\
\hline 1 & 3,148 & 22,488 & 22,488 & 3,403 & 24,310 & 24,310 & 4,903 & 35,022 & 35,022 \\
\hline 2 & 2,785 & 19,889 & 42,378 & 2,685 & 19,175 & 43,485 & 2,502 & 17,870 & 52,891 \\
\hline 3 & 0,983 & 7,024 & 49,401 & 0,986 & 7,043 & 50,528 & 1,107 & 7,904 & 60,796 \\
\hline 4 & 0,871 & 6,220 & 55,621 & 0,915 & 6,533 & 57,061 & 0,847 & 6,050 & 66,846 \\
\hline 5 & 0,844 & 6,026 & 61,647 & 0,876 & 6,260 & 63,322 & 0,785 & 5,610 & 72,457 \\
\hline 6 & 0,806 & 5,758 & 67,405 & 0,811 & 5,794 & 69,115 & 0,668 & 4,770 & 77,227 \\
\hline 7 & 0,677 & 4,839 & 72,244 & 0,679 & 4,850 & 73,966 & 0,617 & 4,405 & 81,632 \\
\hline 8 & 0,676 & 4,832 & 77,076 & 0,620 & 4,431 & 78,396 & 0,467 & 3,336 & 84,968 \\
\hline 9 & 0,612 & 4,370 & 81,446 & 0,556 & 3,970 & 82,367 & 0,445 & 3,180 & 88,149 \\
\hline 10 & 0,570 & 4,071 & 85,517 & 0,546 & 3,903 & 86,270 & 0,411 & 2,936 & 91,085 \\
\hline 11 & 0,550 & 3,928 & 89,445 & 0,520 & 3,712 & 89,981 & 0,369 & 2,632 & 93,717 \\
\hline 12 & 0,533 & 3,805 & 93,250 & 0,509 & 3,633 & 93,614 & 0,326 & 2,326 & 96,043 \\
\hline 13 & 0,495 & 3,533 & 96,783 & 0,477 & 3,408 & 97,022 & 0,306 & 2,188 & 98,231 \\
\hline 14 & 0,450 & 3,217 & 00,000 & 0,417 & 2,978 & 00,000 & 0,248 & 1,769 & 100,000 \\
\hline
\end{tabular}

TABLE 6

ROTATED FACTOR MATRIX OF ITEM AGGREGATES IN RESPECT OF THE DIFFERENT CULTURAL GROUPS (DIRECT OBLIMIN ROTATION)

\begin{tabular}{|c|c|c|c|c|c|c|c|c|}
\hline \multicolumn{3}{|c|}{ Pattern Matrix (Black group) } & \multicolumn{3}{|c|}{ Pattern Matrix (Asian group) } & \multicolumn{3}{|c|}{ Pattern Matrix (White group) } \\
\hline$(n=880)$ & Factor & & $(n=666)$ & Factor & & $(n=117)$ & Factor & \\
\hline Aggregates & 1 & 2 & Aggregates & 1 & 2 & Aggregates & 1 & 2 \\
\hline INT1 & 0,632 & $-0,066$ & INT1 & 0,691 & $-0,023$ & INT1 & 0,749 & $-0,041$ \\
\hline INT2 & 0,651 & $-0,065$ & INT2 & 0,720 & 0,043 & INT2 & 0,644 & $-0,144$ \\
\hline INT3 & 0,691 & $-0,079$ & INT3 & 0,746 & $-0,076$ & INT3 & 0,719 & $-0,067$ \\
\hline INT4 & 0,656 & 0,026 & INT4 & 0,692 & 0,062 & INT4 & 0,739 & 0,103 \\
\hline INT5 & 0,604 & 0,058 & INT5 & 0,603 & 0,085 & INT5 & 0,697 & 0,030 \\
\hline INT6 & 0,453 & 0,139 & INT6 & 0,500 & $-0,002$ & INT6 & 0,720 & 0,092 \\
\hline INT7 & 0,466 & $-0,029$ & INT7 & 0,406 & $-0,077$ & INT7 & 0,691 & $-0,104$ \\
\hline EXT1 & 0,215 & 0,416 & EXT1 & 0,074 & 0,581 & EXT1 & 0,005 & 0,545 \\
\hline EXT2 & 0,034 & 0,519 & EXT2 & 0,029 & 0,587 & EXT2 & $-0,099$ & 0,701 \\
\hline ЕXT3 & $-0,084$ & 0,702 & EXT3 & $-0,099$ & 0,624 & EXT3 & 0,031 & 0,677 \\
\hline EXT4 & 0,023 & 0,568 & EXT4 & 0,029 & 0,549 & EXT4 & 0,034 & 0,557 \\
\hline EXT5 & $-0,103$ & 0,632 & EXT5 & 0,035 & 0,542 & EXT5 & 0,130 & 0,679 \\
\hline EXT6 & $-0,086$ & 0,572 & EXT6 & $-0,054$ & 0,656 & EXT6 & $-0,203$ & 0,605 \\
\hline EXT7 & 0,033 & 0,398 & EXT7 & $-0,036$ & 0,432 & EXT7 & $-0,063$ & 0,439 \\
\hline \multicolumn{3}{|c|}{ Factor Correlation Matrix } & \multicolumn{3}{|c|}{ Factor Correlation Matrix } & \multicolumn{3}{|c|}{ Factor Correlation Matrix } \\
\hline Factor & 1 & 2 & Factor & 1 & 2 & Factor & 1 & 2 \\
\hline 1 & 1,000 & & 1 & 1,000 & & 1 & 1,000 & \\
\hline 2 & 0,139 & 1,000 & 2 & 0,132 & 1,000 & 2 & $-0,317$ & 1,000 \\
\hline
\end{tabular}

0,99 for the different groups and they indicated factor equivalence (Tucker, 1951).

The structural equation model for the two domains underlying the PIB \SpEEx Motivation scales for Black, Asian and White groups are reflected in Figures 4,5 and 6 respectively, with the boxes on the left representing the item parcels hypothesized to define internal locus of control, and those on the right symbolizing the hypothesized indices of the external locus of control. Bentler (1985) suggests that the ratio of sample size to number of estimated parameters may be as low as 5:1 under normal distribution assumptions, and 10:1 for arbitrary distributions. Boomsma (1983) indicates that sample sizes of 100 can be considered a lower boundery for maximum likelihood estimation methods. Jöreskog and Sörbom (1984) and Tanaka (1987) suggest that reasonably robust estimates can be obtained in samples smaller than 200 , depending on the number of parameters estimated in relation to the number of subjects.

With regard to the Black group (Table 8 and Figure 4), the CFI value was 0,903 , the NNFI value was 0,881 and the IFI value was 0,903 . A value of 0,90 is generally considered an indicator of a model that fits well for all of the above-mentioned fit indices (Bentler, 1990; Bentler \& Bonnett, 1980; Steiger, 1995).

The RMSEA value was 0,060. Hair, Anderson, Tatham and Black (1995) regard RMSEA values between 0,05 and 0,08 as indicative of acceptable fit. Steiger (1995) considers RMSEA values of less than 0,10 acceptable.

The chi-square measure was highly significant $\left[\chi^{2}(77)=315,969\right.$; $\mathrm{p} \leq 0,01]$ and indicated a poor model fit. Given the current sample size, it would be inappropriate to conclude poor fit based on the 
significance of the chi-square index. The chi-square/df ratio was 4,2. Ratios between 2 and 5 have been interpreted as indicating a good fit (Kelloway, 1998). Although the NNFI values were marginally lower than the accepted value for a good model fit, it can still be concluded that the two-factor model fits the data reasonably well, as most of the indicators are within the limits of acceptable model fit.

\section{TABLE 7}

CONGRUENCE COEFFICIENTS IN RESPECT OF THE DIFFERENT CULTURAL GROUPS

\begin{tabular}{lcc}
\hline \multicolumn{3}{c}{ EXTERNAL LOCUS OF CONTROL: } \\
\hline Main groups & Black & Asian \\
\hline Asian & 0,99 & \\
White & 0,99 & 0,98 \\
\hline & INTERNAL LOCUS & OF CONTROL: \\
\hline Main groups & Black & Asian \\
\hline Asian & 0,98 & \\
White & 0,96 & 0,97 \\
\hline
\end{tabular}

TABLE 8

FIT INDICES IN RESPECT OF THE DIFFERENT CULTURAL GROUPS

\begin{tabular}{lccc}
\hline Main groups & Black $(\mathrm{n}=880)$ & Asian $(\mathrm{n}=666)$ & White $(\mathrm{n}=117)$ \\
\hline Chi-square & 315,969 & 291,050 & 135,143 \\
(df) & $(76)$ & $(76)$ & $(76)$ \\
CFI & 0,903 & 0,893 & 0,899 \\
NNFI & 0,881 & 0,872 & 0,879 \\
IFI & 0,903 & 0,894 & 0,902 \\
RMSEA & 0,060 & 0,066 & 0,082 \\
\hline
\end{tabular}

In respect of the Asian group (Table 8 and Figure 5), the CFI value was 0,893 . The NNFI value was 0,872 and the IFI value was 0,894 . The RMSAE value was 0,067 . The chisquare $\left[\chi^{2}(76)=291,050 ; \mathrm{p} \leq 0,01\right]$ was statistically significant. The chi-square/df ratio of 3,83 was within the acceptable range, indicating good model fit. The RMSAE and the chi-square/df ratio indices indicated an acceptable model fit for the data. The CFI and IFI values were very close to the 0,90 level, indicating a reasonable model fit. The NNFI value was slightly lower than can be considered an acceptable model fit. Overall, it can be concluded that the two-factor model fitted the data reasonably well, as most indicators were very close to or within the limits of acceptable model fit.
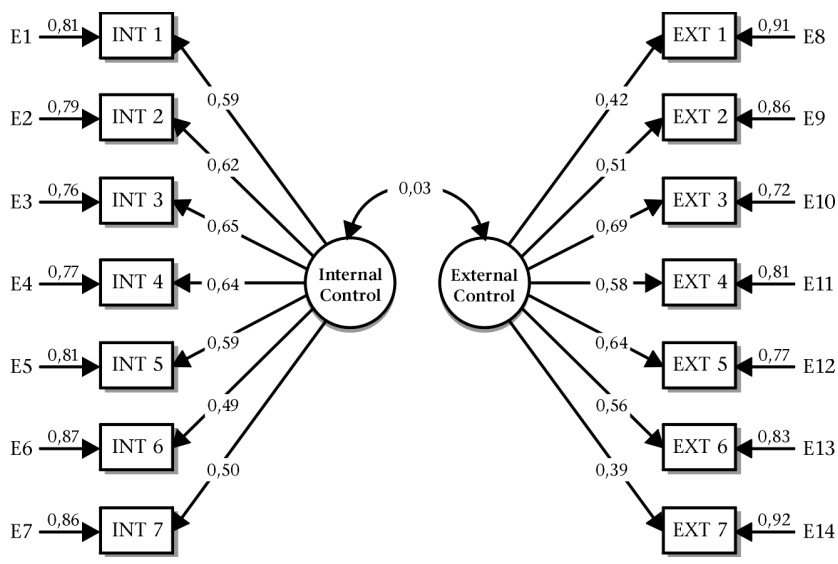

Figure 4: Standardised estimated parameters of the PIB/ SPEEX Motivation Index for the Black group
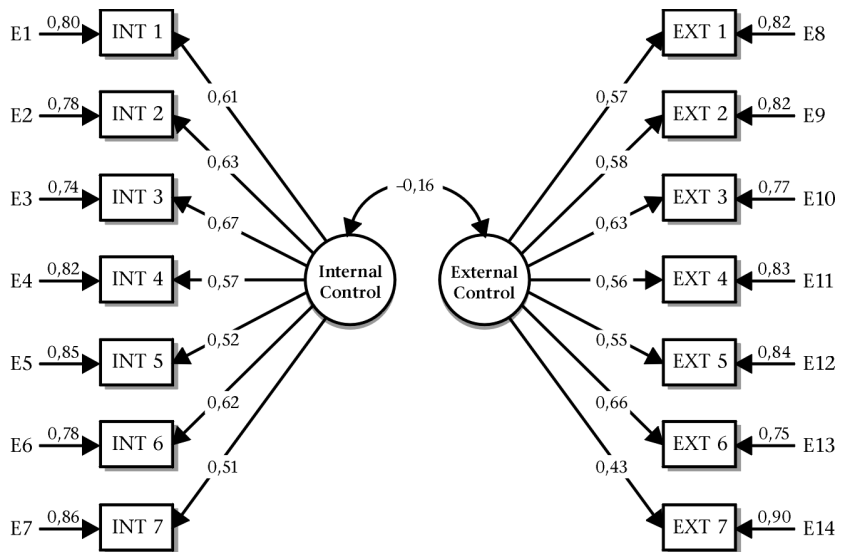

Figure 5: Standardised estimated parameters of the PIB/ SPEEX Motivation Index for the Asian group

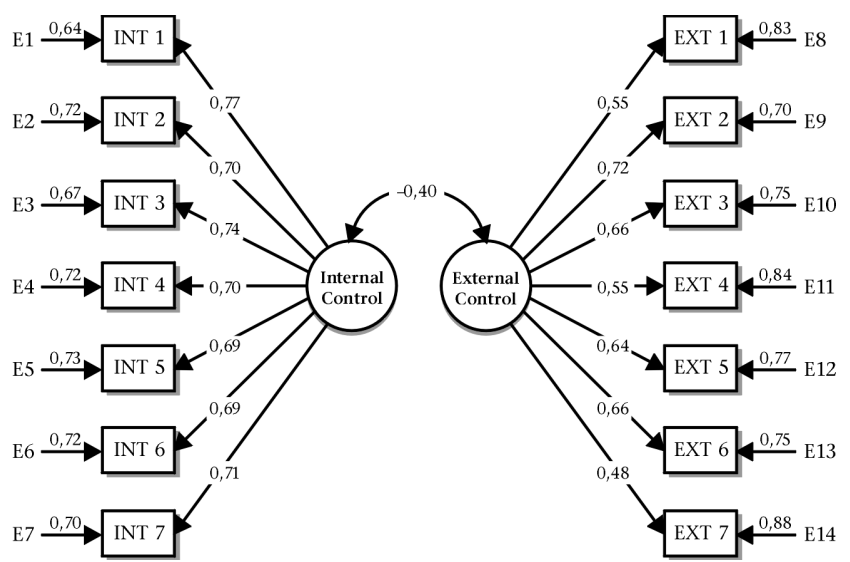

Figure 6: Standardised estimated parameters of the PIB/ SPEEX Motivation Index for the White group

TABLE 9

RESULTS OF THE MULTIPLE-GROUP ANALYSIS

\begin{tabular}{|c|c|c|c|c|c|c|c|c|}
\hline Model & $\chi^{2}$ & $D f$ & $\Delta \chi^{2}$ & $\Delta d f$ & CFI & NNFI & IFI & RMSEA \\
\hline Equal covariances matrices & $370,602^{*}$ & 126 & NA & NA & NA & NA & & \\
\hline Null model a & $5331,657^{*}$ & 273 & NA & NA & NA & NA & & \\
\hline \multicolumn{9}{|l|}{ Nested models } \\
\hline Equal factor model & $742,162 *$ & 228 & NA & NA & 0,898 & 0,878 & 0,899 & 0,037 \\
\hline Equal factor variances & $750,759 *$ & 232 & 8,597 & 4 & 0,897 & 0,879 & 0,898 & 0,037 \\
\hline Equal factor covariances & $767,841^{*}$ & 234 & 17,082 * & 2 & 0,894 & 0,877 & 0,895 & 0,037 \\
\hline Equal factor loadings & $827,406^{*}$ & 258 & $59,655^{*}$ & 24 & 0,887 & 0,881 & 0,888 & 0,037 \\
\hline Equal factor loadings $b$ & $798,876^{*}$ & 256 & 31,035 & 22 & 0,893 & 0,886 & 0,893 & 0,036 \\
\hline
\end{tabular}

a Model for independent variables (baseline model)

b The constraints on aggregates ET3 an ET4 have been relaxed with respect to Black and Asian groups

Statistical significance: ${ }^{*}=\mathrm{p} \leq 0,05$ 
With regard to the White group (Table 8 \& Figure 6), the CFI value was 0,899 . The NNFI value was 0,879 and the IFI value was 0,902 . The RMSAE value was 0,082 . The chi-square $\left[\chi^{2}(76)=\right.$ $135,143 ; \mathrm{p} \leq 0,01]$ was statistically significant. The chi-square/df ratio of 1,78 was within the acceptable range indicating good model fit. The CFI and the NNFI indicated a model fit for the data that come very close to what can be considered acceptable. The IFI, RMSAE and chi-square/d.f ratio fit indices indicated an acceptable to good model fit for the data. Thus, it can be concluded that the two-factor model fitted the data reasonably well, as most indicators were very close to or within the limits of acceptable model fit.

Overall, the single group confirmatory factor analysis fit indices were very similar for the groups included in the study and indicated the equivalence of the constructs for these groups.

The results of the multiple-group analysis are set out in Table 9 . The chi-square test for equality of covariances matrices was statistically significant $\left[\chi^{2}(126)=370,602 ; p \leq 0,01\right]$ indicating that the covariance matrices were not equal for the Black, Coloured and White groups. The series of hierarchically nested models indicated statistically significant chi-square values for all the constraints. Chi-square is known to be sensitive to sample size and large samples tend to yield significant values with regard to small differences. The statistically non-significant change in chi-square values of the test for equality of factor variance $\left[\Delta \chi^{2}(4)=8,597\right.$; $\mathrm{p}>0,05]$ indicated that the factor variances could be considered equal for Black, Coloured and White groups. The change in chisquare values was significant for equal factor covariance $\left[\Delta \chi^{2}(2)\right.$ $=17.082 ; \mathrm{p} \leq 0,05]$ and factor loadings $\left[\Delta \chi^{2}(24)=59,655 ; \mathrm{p} \leq 0,05\right]$ for the Black, Coloured and White groups. Van de Vijver and Leung (2001, p 1018) argue that factor loadings constitute the heart of the model while factor covariance is often considered less important and has fewer consequences for structural equivalence. Van de Vijver and Leung (1997) suggest that a better model fit for equal factor loadings may be found when the constraint on a subset of factor loadings is released. If this is the case, subtle differences in the psychological structure have been observed. The LM test revealed low probability values for the constraints on the aggregates ET3 $\left[\chi^{2}(1)=18,744 ; \mathrm{p}=0,000\right]$ and ET5 $\left[\chi^{2}(1)=9,854\right.$; $p=0,002]$ for the Black and Asian groups. In a subsequent analysis the constraints on the aggregates ET3 and ET5 for these groups were released with regard to the model for equal factor loadings, resulting in a non-significant change in chi-square $\left[\Delta \chi^{2}(22)=\right.$ $31,035 ; p>0,05]$. These results could be an indication of subtle differences in the psychological structure of the PIB/SpEEX Motivation Index for the Black and Asian groups.

The CFI and IFI values in Table 9 for the equal factor model, equal factor variance, equal factor covariance and equal factor loading constraints were all very close to 0,90 , indicating a reasonable model fit. The RMSEA values were all below 0,05 for all the constraints, indicating good model fit. The NNFI values were less optimal for the sequence of nested models. An observable improvement in the values of all the model fit indices for the equal factor loading constraint occurred after the constraints on the aggregates ET3 and ET5 were released for the Black and Asian groups.

It is evident from the results of the exploratory and confirmatory factor analyses that the two-factor solution for the PIB $\backslash$ SpEEx Motivation scales held reasonably to very well for the three groups included in the study.

\section{DISCUSSION}

It can be concluded that the item statistics for the PIB/SpEEx scale can be considered acceptable for the Black, Asian and White groups. Thus, most of the items meet the minimum requirements in terms of their relation to the scales of the PIB/SpEEx Motivation Index for the Black, Asian and White groups.

The difference in PIB/SpEEx scale reliabilities was nonsignificant for the Black and Asian groups, which may indicate that the constructs are equivalent for these groups. Statistical significant differences in scale reliabilities for the Black and White groups provided some indication that the PIB/SpEEx Motivation constructs may not be equivalent for these groups. However, it should be recognized that differences that exist in scale reliabilities between groups could be considered preliminary, and not as conclusive, evidence. Therefore, factor analyses were required to provide more conclusive evidence. It should be noted that the scale reliabilities were all well within the range of what generally is considered acceptable for the Black, Asian and White groups.

The results of the exploratory factor analysis indicated similar response patterns on the External Locus of Control and Internal Locus of Control scales for the Black, Asian and White groups. The inter-scale correlation analyses and the exploratory factor analyses indicated that the data sets of all of the groups revealed a clear distinction between the internal locus of control and the external locus of control constructs. The congruence coefficients obtained emphasise the equivalence of the locus of control constructs for the Black, Asian and White groups.

The results of the confirmatory factor analyses strongly supported the two-factor model, the equality of factor variances and factor loadings of the PIB/SpEEX Motivation Index for the Black, Asian and White groups, but it should be noted that subtle differences between the Black and Asian group were observed on the factor loadings of the External Locus of Control scale. These could be ascribed to the effect of sample size and were considered to be of less importance for construct equivalence. The equality of factor covariance between the PIB/SpEEx constructs could not be verified by means of a change in the chi-square statistic for the Black, Asian and White groups. The CFI and IFI values (who are less sample sensitive) and the RMSEA values indicated a reasonable to acceptable model fit for all the constraints set. The observed variation in factor covariance for the Black, Asian and White groups could be considered small and consequently of less importance for the construct equivalence of the PIB/SpEEx Motivation Index.

The results of the exploratory and confirmatory factor analysis that are reported in the study provide confirmation of Van de Vijver and Leung's (2001) finding that exploratory and confirmatory factor analysis does not always provide identical conclusions about the equivalence of factor structures. More specifically, the latter appears to provide a stricter test for the equivalence of factor structures. Construct equivalence is consequently more difficult to attain, sometimes for psychologically unclear or trivial reasons. This is especially true for large sample multiple-group comparisons, due to the sample sensitivity of the chi-square statistic.

Overall, it can be concluded that the constructs of the PIB/SpEEx Motivation Index appear to be equivalent for the Black, Asian and White groups. The results of this study provide strong support for concluding that the English version of the PIB/SpEEX Motivation Index is a valid and culturally non-biased measure of the locus of control construct for entrylevel job applicants in the public safety and security sector in South Africa. However, it must be recognised that the respondents linguistic abilities in English and their conceptual reasoning abilities should be of a sufficiently high level and relatively homogeneous for Black, Asian, and White groups for the above conclusion to be valid. It is thus recommended that cognitive and English linguistic ability measures be used as initial screening devices before the PIB/SpEEx Motivation Index is applied. 


\section{REFERENCES}

Anastasi, A \& Urbina, D. (1997) Psychological testing (7th ed). Upper Saddle River, NJ: Prentice-Hall.

Anderson, H.N., Madonna, S., Bailey, G.K. \& Wesley, A.L. (1987). Further considerations of the multidimensionality and factor structures of the Rotter Locus of Control Scale. Psychological Reports, 60, 1059-1062.

Bagozzi, R.P. \& Heatherton, T.F. (1994). A general approach to presenting multifaceted personality constructs: Application to state self-esteem. Structural Equation Modelling, 1, 35-67.

Bechger, T.M., Van den Wittenboer, G., Hox, J.J. \& De Glopper, C. (1999). The validity of comparative educational studies. Educational Measurement: Issues and Practice, 18 (3), 18-26.

Bentler, P.M. (1985). Theory and implementation of EQS: A structural equations program. Los Angeles, CA: BMDP Statistical Software.

Bentler, P.M. \& Bonnett, D.G. (1980). Significance tests and goodness of fit in the analysis of covariance structures. Psychological Bulletin, 88 (3), 588-606.

Bentler, P.M. (1990). Comparative Fit Indexes in Structural Models. Psychological Bulletin, 107 (2), 238-247.

Bentler, P.M. (1995). EQS Structural Equations Program Manual. Encino, CA: Multivariate Software.

Bergh, Z.C. (1999). Work adjustment. In Z. C. Berg \& A.L. Theron (eds), Psychology in the work context. Johannesburg: International Thomson Publishing.

Blau, G (1993). Testing the relationship of locus of control to different performance dimensions. Journal of Occupational and Organisational Psychology, 66 (2), 125-139.

Boomsma, A. (1983). On the robustness of LISREL (maximum likelihood estimation) against small sample size and nonnormality. Unpublished doctoral dissertation, University of Groningen.

Buriel, R. (1981). The relation of Anglo and Mexican-American children's locus of control beliefs to parents' and teachers' socialization practices. Child Development, 52, 104-113.

Byrne, B.M., Shavelson, R.J. \& Muthén, B. (1989). Testing for the equivalence of factor covariance and mean structures: The issue of partial measurement invariance. Psychological Bulletin, 105, 456-466.

Cattell, R.B. (1966). The scree test for the number of factors. Multivariate Behaviour Research, 1, 245-276.

Charter, R.A. \& Feldt, L.S. (1996). Testing the equality of two alpha coefficients, Perceptual and Motor Skills, 82, 763-768.

Child, D. (1990) The essentials of factor analysis ( $2^{\text {nd }}$ ed). London: Cassell Educational.

Chiu, L. (1988). Locus of control differences between American and Chinese adolescents. Journal of Social Psychology, 128, 411-413.

Comrey, A.L. \& Lee, H.B. (1992). A first course in factor analysis. Hillsdale, New Jersey: Lawrence Erlbaum.

Dean, S.A. (1984). External locus of control and career counseling for Black youth. Journal of Non-White Concerns in Personnel and Guidance, 12, 110-116.

DeVellis, R.F. (1991). Scale development: theory and applications. Newbury Park: Sage Publications.

Duffy, P.J., Shiflett, S. \& Downey, R.G. (1977). Locus of control: dimensionality and predictability using Likert scales. Journal of Applied Psychology, 62 (2), 214-219.

Erasmus, P.F. (2001). Situation specific job profiling and assessment in the workplace of the $21^{\text {st }}$ century. Johannesburg: Potential Index Associates.

Erwee, R. (1986). Achievement motivation and locus of control of Black University students. Journal of Industrial Psychology, 12 (2), 1-9.

Gorsuch, R.L. (1983). Factor analysis (2nd edition). Hillsdale, NJ: Lawrence Erlbaum Associates.

Gorsuch, R.L. (1997). Exploratory factor analysis: its role in item analysis. Journal of Personality Assessment, 68 (3), 532-560.
Grieve, K.W. (2001). Factors affecting assessment results. In: C. Foxcroft \& G. Roodt (eds.) An introduction to psychological assessment in the South African context. Cape Town: Oxford University Press.

Grobler, S. (2000). Die geldigheid van die Potensiaalindeksbattery vir die voorspelling van kollegeprestasie by toetreekonstabels in die Suid-Afrikaanse Polisiediens. MCom dissertation: University of Pretoria.

Hair, J.F., Anderson, R.E., Tatham, R.L. \& Black, W.C. (1995) Multivariate data analysis with readings. Upper Saddle River NJ: Prentice-Hall.

Heaven, P., Rajah, D. \& Bester, C.L. (1986). Hostility and locus of control in South Africa. Personality and Individual Differences, 7, 415-417.

Hersch, P.D. \& Scheibe, K.E. (1967). Reliability and validity of internal-external control as personality dimensions. Journal of Consulting Psychology, 31, 609-613.

Horn J.L. (1965). A rationale and test for the number of factors in factor analysis. Psychometrika, 30 (2):179-185

Horne, T.J. (2001). Education and language transferees. The Education African Forum, 5. In press.

Jöreskog, K.G. \& Sörbom, D. (1984). LISREL VI: Analysis of linear structural relationships by the method of maximum likelihood, instrumental variables, and least squares methods. Mooresville, IN: Scientific Software.

Kaiser, H.F. (1961) A note on Guttman's lower bound for the number of common factors. British Journal of Statistical Psychology, 14 (1),1.

Kanji, G.K. (1993). 100 statistical tests. London: SAGE Publications.

Kelloway, E.K. (1998). Using LISREL for structural equation modeling; a researcher's guide. Thousand Oaks: Sage Publications.

Kim, J. \& Mueller, C.W. (1978). Factor Analysis: Statistical methods and practical issues. Sage University Paper series on Quanitative Applications in the Social Sciences, Series no 07014. Beverly Hills and London: Sage Publications.

Kishor, N. (1983). Locus of control and academic achievement Ethnic discrepancies among Fijians. Journal of Cross-cultural Psychology, 14, 297-308.

Kriel, H. (1999). Horses for courses: Situation-specific selection revised. Unpublished Report: Technikon Pretoria.

Kruger, J.R. (1999). Die geldigheid van die Potensiaalindeksbattery vir die voorspelling van werkprestasie by administratiewe personeel. MCom dissertation: University of Pretoria.

Kureshi, A. \& Husain, A. (1981). Locus of control among Indian, Iranian and Palestinian students. Psychological Studies, 26, 1-2.

Le Roux, C.A., Schmidt, C. \& Schepers, J.M. (1997). Achievement motivation, locus of control and individuality as predictors of participative management in the South African context. Journal of Industrial Psychology, 23 (3), 1-8.

Lewin, K. (1935). A dynamic theory of personality. New York: Mcgraw-Hill.

Macan, T.H. \& Trusty, M.L. (1996). Spector's work locus of control scale: Dimensionality and validity evidence. Educational and Psychological Measurement. 56 (2), 349-358.

MacCallum, R. (1986). Specification searches in covariance structure modeling. Psychological Bulletin, 100, 107-120.

Marsh, H.W., Balla, J.R. \& McDonald, R.P. (1988). Goodness-offit indexes in confirmatory factor analysis: The effect of sample size. Psychological Bulletin, 103 (3), 391-410.

McDonald, R.P. (1985). Factor analysis and related methods. Hillsdale, NJ: Erlbaum.

Medskar, G.J., Williams, L.J. \& Holahan, P.J. (1994). A review of current practices for evaluating causal models in organisational behavior and human resources management research. Journal of Management, 20, 439-464.

Mirowsky, J. \& Ross, C.E. (1984). Mexican culture and its emotional contradictions. Journal of Health and Social Behaviour, 25, 2-13. 
Mischel, W. (1968). Personality and Assessment. New York: Wiley.

Otterman, Y. (1999). http://miavx1.muohio.edu/ psybersite/ control/culture.htx.

Owen, K. (1996). Test bias and test fairness. In: K. Owen \& J.J Taljaard (eds.). Handbook for the use of Psychological and Scholastic tests of the HSRC. Pretoria: Human Sciences Research Council.

Republic of South Africa (1998). Employment Equity Act. Pretoria: Government Printer.

Reynolds, C.R. (1982). The problem of bias in psychological assessment. In C.R. Reynolds \& T.B. Gutkin (eds.). The handbook of school psychology. New York: Wiley

Robbins, S.P. (2001). Organisational behaviour. (9th ed). Englewood Cliffs, NJ: Prentice Hall.

Rotter, J.B. (1966) "Generalized expectancies for internal versus external control of reinforcement" Psychological Monographs, 80 (1), no 609.

Schaap, P. (1998). Technical data: Uni-Pib 2000. Unpublished report: University of Pretoria.

Schaap, P. (2001) Determining differential item functioning and its effect on the test scores of selected PIB Indexes, using item response theory techniques. Journal of Industrial Psychology, 27 (2), 32.

Schepers, J.M. (1995) Locus of control inventory. Unpublished report: Rand Afrikaans University.

Spector, P.E. (1982). Behaviour in organisations as a function of employees' locus of control. Psychology Bulletin, 91, 482-497.

SPSS Inc. (1996). SPSS for Windows, Version 10.1 [computer software]. Chicago: SPSS.

Steers, M.R. \& Porter. L.W. 1991. Motivation and work behaviour. Singapore: McGraw-Hill.

Steiger, J.H. (1995). Manual to Statistica-SEPATH. Tulsa, OK:Statsoft.

Tabachnick, B.G. \& Fidell, L.S. (1989). Using multivariate statistics ( $2^{\text {nd }}$ ed). New York: Harper Collins Publishers.

Tanaka, J.S. (1987). "How big is big enough": sample size and the goodness of fit in structural equation models with latent variables. Child Development, 58, 134-146.

Tinsley, H.E.A., \& Tinsley, D.J. (1987). Using factor analysis in counselling psychology research. Journal of Counselling Psychology, 34, 414-424.
Tucker, L.R. (1951). A method for synthesis of factor analysis studies. Personnel Research Section Report, No 984. Washington, D.C.: Department of the Army.

Ungerer, L. (1999). Cognition. In: Z.C. Bergh \& A.L. Theron (Eds). Psychology in the work context. Johannesburg: International Thomson Publishing.

Van Daalen, H.J., Van Niekerk, E.C. \& Pottas, C.D. (1989) The validation of Furnham's Locus of Control scale for a Black Southern African group. Journal of Industrial Psychology, 15 (1), 12-21.

Van de Vijver, F. J. R. \& Harsveld, M. (1994). The incomplete equivalence of the paper and pencil and computerized versions of the General Aptitude Test Battery. Journal of Applied Psychology, 79, 852-859.

Van de Vijver, F. J. R. \& Leung, K. (1997). Methods and data analysis of comparative research. In: J. W. Berry, Y. H. Poortinga, \& J. Pandey (eds.). Handbook of cross-cultural psychology. (2 $2^{\text {nd }}$ ed. Vol. 1). Boston: Allyn \& Bacon.

Van de Vijver, F. J. R. \& Leung, K. (2001). Personality in cultural context: Methodological issues. Journal of Personality, 69, 1007-1031.

Van de Vijver, F. J. R. \& Poortinga, Y. H. (2000). Structural equivalence in multilevel research. Tilburg: Tilburg University. (in preparation)

Van de Vijver, F. J. R. \& Tanzer, N. K. (1997). Bias and equivalence in cross-cultural assessment: An overview. European Review of Applied Psychology, 47, 263-280.

Van Staden, J.F., Schepers, J.M. \& Rieger, H.S. (2000). Lokus van beheer en transformasionele leierskap. Tydskrif vir Bedryfsielkunde, 26 (3), 8-14.

Vandenberg, R J. \& Self, R.M. (1993). Assessing newcomers' changing commitments to the organisation during the first 6 months of work. Journal of Applied Psychology, 78 (4), 557-568.

Young, J.W. \& Shorr, D.N. (1986). Factors affecting locus of control in school children. Genetic, Social, and General Psychology Monograms, 112, 405-417.

Zwick, W.R. \& Velicer, W.F. (1986). A comparison of five rules for determining the number of components in complex datasets. Psychological Bulletin, 99, 432-442. 